\title{
ECOSYSTEM REGULATION SERVICES IN AQUATIC ENVIRONMENTS: THE CASE OF IBIRITÉ RESERVOIR, MINAS GERAIS
}

\author{
Francisco Antônio Rodrigues Barbosa ${ }^{1 *}$, Maria Margarida Marques ${ }^{l}$, Pedro Maia-Barbosa ${ }^{I}$, Aline \\ Morena Menezes Santos ${ }^{l} \&$ Marcelo Augusto Rezende Costa ${ }^{l}$ \\ ${ }^{1}$ Federal University of Minas Gerais (UFMG), Institute of Biological Sciences, Limnology Laboratory. Av. Antonio Carlos, 6627, Campus Pampulha, \\ Belo Horizonte, Minas Gerais, Brasil. CEP: 31270-911. \\ E-mails: barbosa@icb.ufmg.br, mmarques@icb.ufmg.br, pebarbosa.limno@gmail.com, alinemorenapj@gmail.com,marcelo@icb.ufmg.br
}

\begin{abstract}
This chapter presents the physical, chemical and biological features of water collections within the watershed of Ibirité reservoir with which were made comparisons among limnological variables, namely water temperature, concentrations of dissolved oxygen, nutrients (ammonium-, nitrite, nitrate-, and total nitrogen, soluble reactive phosphorus, total phosphorus), along with chlorophyll-a, algae richness and density from sampling points upstream the reservoir (point 1C), within the reservoir (points 2, 3, 4) and just downstream the reservoir (point 10). These comparisons allowed the verification of a significant reduction of nutrient and chlorophyll-a concentrations and the increase of oxygen concentration at point 10 which were used to demonstrate the effectiveness of ecosystem services, namely recovery and provisioning of water quality provided by the reservoir and that are essentials for the maintenance of aquatic communities, particularly the phytoplankton one.
\end{abstract}

Keywords: Nutrient retention; water quality; eutrophication control; conservation of phytoplankton richness and diversity.

\section{RESUMO}

SERVIÇOS ECOSSISTÊMICOS DE REGULAÇÃO EM AMBIENTES AQUÁTICOS: O CASO DO RESERVATÓRIO DE IBIRITÉ, MINAS GERAIS. Este trabalho apresenta as características físicas, químicas e biológicas de amostras de água dentro da bacia hidrográfica do reservatório de Ibirité com as quais foram feitas comparações entre variáveis liminológicas, temperatura da água, concentração de oxigênio dissolvido, nutrientes (amônia, nitrito, nitrato, e nitrogênio total, fósforo solúvel reativo, fósforo total), juntamente com clorofila-a, riqueza e densidade de algas de pontos de amostragem a montante do reservatório (ponto 1C), dentro do reservatório (pontos 2, 3, 4) e logo a jusante do reservatório (ponto 10). Estas comparações permitiram a verificação de uma redução significativa nas concentrações de nutrientes e clorofila-a e o aumento da concentração de oxigênio no ponto 10 que foram usados para demonstrar a eficácia dos serviços do ecossistema, especialmente recuperando e promovendo a qualidade da água do reservatório que são essenciais para a manutenção das comunidades aquáticas, particularmente a de fitoplâncton.

Palavras-chave: Retenção de nutrientes; qualidade da água; controle da eutroficação; conservação da riqueza e diversidade do fitoplâncton. 


\section{INTRODUCTION}

According to the Millennium Ecosystem Assessment's concept (2005a), ecosystem services are all the direct or indirect benefits that human beings can obtain from the functioning of the ecosystems. The ecosystem services derive from the multiple processes and the complex interactions between the biotic (living beings) and abiotic (physical and chemical matrix) of the environments; the maintenance of such processes and, thus, the maintenance of the services, can only be guaranteed with the preservation of the structural elements that form the integrity of each ecosystem (Andrade \& Romeiro 2009).

The Millennium Ecosystem Assessment (2005a) proposes a classification of the ecosystem services in four categories:

i) provisioning (or supplying) services: include the products obtained from the ecosystems such as food and fibers, wood and other material that serve as fuel and energy source, genetic resources, biochemical, medical and pharmaceutical products, ornamental resources, and water;

ii) regulation services: related to the regulatory characteristics of the ecosystem processes, such as maintenance of air and climate quality, erosion control, water purification, residue treatment, regulation of human diseases, regulation of agricultural plagues, pollination and protection against natural disasters;

iii) cultural services: include the cultural diversity of the human societies, since the diversity of the ecosystems itself provides the multiplicity of the cultures, of religious and spiritual values, the generation and transmission of knowledge (formal and traditional), educational and esthetical values;

iv) supporting services: important for the production and maintenance of all the other services since they provide the structural basis for the others to occur. Primary production, atmospheric oxygen production, soil formation and retention, nutrient cycling, water cycling and habitat provisioning are some examples.

The continental aquatic ecosystems, natural or artificial, permanent or temporary usually offer services in each of these four categories, since they supply water for human consumption, as well as fish and fibers (provision), contribute to the climate maintenance, regulation of floods or droughts, and water quality (regulation), supply scenarios in which the relationships between men and the environment take place, as well as the opportunity of leisure, recreation, tourism (cultural) and, because water is essential to every living being, they offer support for all the other services to occur (support) (Millennium Ecosystem Assessment 2005b).

The construction of barriers to retain running waters is one of the metain strategies used to guaranteeing water supply for human consumption, irrigation and energy supply. Such infrastructure sites cause significant impacts in the aquatic systems and their biota. However, they also allow a better use of the water resources. One of the main alterations caused by the retaining of rivers is the change in the transport index of organic and inorganic matter from upstream to downstream, since a large amount of the material transported by the flow is retained in the barrier (Straškraba et al. 1995). Even if this kind of impact does have negative consequences to the environment, in some cases the retaining of suspended particulate matter can lead to an improvement in the water quality upstream either by dilution, sedimentation, or incorporation of polluting substances into the organisms' biomass, mainly aquatic macrophytes (Reddy 1983).

Small tropical reservoirs eutrophicated because of large amounts of organic charges launched in their tributaries are good examples of how physical barriers imposed on the water flow contribute to the water purification and improve its quality downstream the reservoir (Fiala \& Vasata 1982) thus realizing an important physical, chemical and biological quality regulation service (Barbosa et al. 1999).

In the present study, the service of water depuration/purification at Ibirite reservoir through the retention of nutrient elements and releasing waters of considerable better quality downstream was assessed through comparisons of physical and chemical data. The water quality conditions within the reservoir was taken as reference and compared with physical and chemical variables measured just downstream the dam in order to demonstrate the changes between these two compartments.

\section{MATERIALS AND METHODS}

\section{STUDY AREA}

Ibirité reservoir is located within the Rio Paraopeba watershed, one of the main contributors of the upper 
São Francisco watershed in the state of Minas Gerais. This watershed comprises an area of $12,092 \mathrm{~km}^{2}$ with 35 municipalities and a total population of 909,486 inhabitants (Igam 2007). The municipality of Ibirite, with c. 133,000 inhabitants has its economy based on vegetables and mining, and is characterized as a "sleep-over town". The Gabriel Passos Refinary (Regap-Petrobrás), with more than half of its territory located in this municipality together with the Aureliano Chaves Thermal Electric Mill (Ibiritermo), established in 2002 to provide energy to Petrobrás' plant are two particularly important plants depending on the waters of Ibirité reservoir. Furthermore, this reservoir although important to the municipally and the region's companies, has been widely impacted by several activities, such as domestic sewage deposition without any previous treatment, that resulted in a large degradation of its waters, which are today heavily eutrophicated thus exhibiting frequent algae blooms, including some with toxic potential.

The studies were conducted by measurements and samplings at 5 sampling points, identified as follows (Figure 1):

i) Point 1C: Mouth of Ibirité stream $\left(20^{\circ} 00^{\prime}\right.$ 20.2" S; 44 06' 20.2" W);

ii) Point 2: Ibirité reservoir, next to the Dam

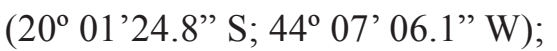

iii) Point 3: reservoir, next to the CEPE/ Petrobrás $\left(20^{\circ} 01^{\prime} 34.6^{\prime \prime} \mathrm{S}\right.$; $\left.04^{\circ} 06^{\prime} 24.5 \mathrm{~W}\right)$;

iv) Point 4: reservoir, next to the mouth of Ibirité stream ( $20^{\circ} 03^{\prime} 2.7^{\prime \prime} \mathrm{S}$; 44 $04^{\circ} 32.2^{\prime \prime}$ W);

v) Point 10: just downstream Ibirité reservoir

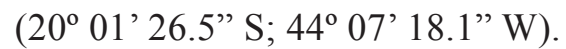

These points were sampled at bimonthly intervals throughout the period of August 2007 and June 2009, totaling 12 sampling campaigns.

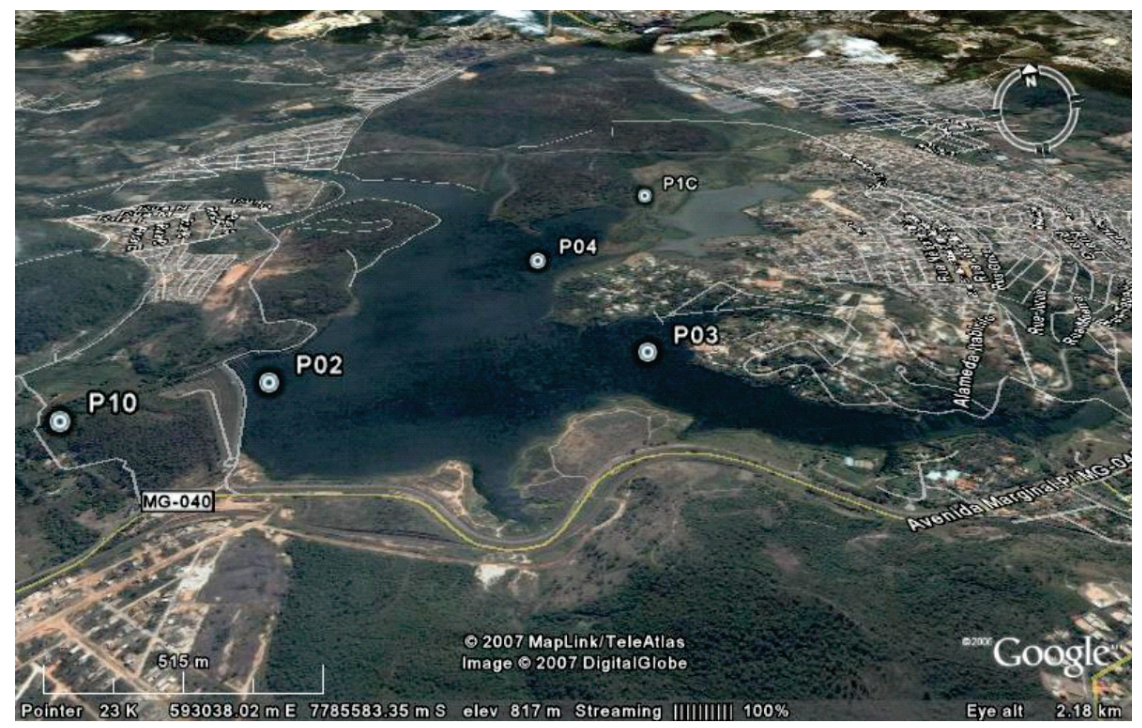

Figure 1. The Ibirité reservoir watershed showing the sampling points. Source: Google Earth Image, obtained in May 2007.

Figura 1. O reservatório da bacia hidrográfica de Ibirité e os pontos de amostragem. Fonte: Imagem do Google Earth, obtida em maio de 2007.

\section{VARIABLES MEASURED AT THE WATER COLUMN}

In each sampling campaign the determination of limnological variables (temperature, electric conductivity, $\mathrm{pH}$, dissolved oxygen, turbidity and oxidation/reduction potential) was done in situ by means of a HORIBA-U22 multi-probe, at $0.5 \mathrm{~m}$ intervals along the water column. Water transparency was estimated by the depth of visual disappearance of the Secchi disc assuming, with Cole (1983) this depth corresponds to $c .10 \%$ of the light reaching the surface.

For the determinations of total nitrogen, nitrate-, nitrite-nitrogen, total and soluble reactive phosphorous methodologies described by Mackereth et al. (1978) were used. For the ammonium-nitrogen concentration the methodology described by Koroleff (1976) was used, and for the "silicate" concentration the one described by Golterman et al. (1978). The 
determination of chlorophyll-a was done according to Lorenzen (1967).

\section{PHYTOPLANKTON COMMUNITY}

The samplings for richness evaluation were collected with a plankton net of $20 \mu \mathrm{m}$ mesh size through vertical and horizontal net hauling at the water column (points 2, 3, 4 at Ibirité reservoir; points 1C and 10 at the central channel, stored in polyethylene flasks $(200 \mathrm{~mL})$ after fixation with $4 \%$ phormoldehide solution. In the laboratory, 10 glass slides for each sampled point were prepared, analyzed and photographed under an optical microscope (Olympus BX 41) in order to identify the individuals from the community at the lowest possible taxonomic level, with the help of a specific bibliography (Bourrely 1968, 1972, 1985, Prescott 1975, Sant'Anna 1984, Rodrigues 1988, Bicudo \& Menezes 2005).

For the quantitative analysis the samples were collected at the subsurface $(0.5 \mathrm{~m})$, in points along the river (points $1 \mathrm{C}$ and 10), directly with the polyethylene flask $(200 \mathrm{~mL})$ and at the Secchi disc depth (points 2, 3 and 4) and fixed with acetic lugol solution. The individuals' counting was realized in sedimentation chambers of known volume (10, 25 and $50 \mathrm{~mL})$ in an inverted microscope using the Utermöhl technique (Utermöh 1958) and sedimentation timing according to Lund et al. (1958). The density of organisms was calculated with the Vilafañe \& Reid (1995) equations and expressed in organisms. $\mathrm{mL}^{-1}$.

\section{DATA TREATMENT}

For the comparison between the points downstream and upstream the reservoir Mann-Whitney tests were realized using the physical, chemical and biological parameters with the PAST program (Hammer et al. 2001).

\section{RESULTS}

The two lotic areas studied (Points I-C, upstream and 10, downstream the reservoir) showed extremely low water quality conditions indicating the prevailing degradation around the Ibirité reservoir. Moreover, points $1 \mathrm{C}$, the reservoir's main tributary and 10 , the water's exit, showed variables with similar temporary patterns with however, a slight improvement in water quality at this area, which can been seen by the significant differences in the concentrations of total-P, soluble reactive phosphorus, total-N, ammoniumnitrogen, dissolved oxygen, total dissolved solids, electrical conductivity and turbidity.

The waters of Ibirité stream at point $1 \mathrm{C}$, just before entering the reservoir, varied from slightly acidic to slightly alkaline, with high electrical conductivity $\left(>500 \mu \mathrm{S} . \mathrm{cm}^{-1}\right.$ ). Water temperature showed a strong seasonal influence with the lowest values registered in June and August. The environment's oxygenation was compromised during most of the time with levels frequently below $5.0 \mathrm{mg} \cdot \mathrm{L}^{-1}$. At the last three campaigns however, since February 2009, values over $6.0 \mathrm{mg} . \mathrm{L}^{-1}$ were registered.

As for the phosphorous concentrations, both the maximum values of total-P and soluble reactive- $\mathrm{P}$ were registered in June 2009 (respectively 902.3 $\mu \mathrm{g} . \mathrm{L}^{-1}$ and $\left.630.1 \mu \mathrm{g} . \mathrm{L}^{-1}\right)$. On the other hand, the minimum values for these nutrients were recorded respectively in December and February 2008 (160.2 $\mu \mathrm{g} . \mathrm{L}^{-1}$ for total phosphorous and $13.9 \mu \mathrm{g} . \mathrm{L}^{-1}$ for soluble reactive phosphorous).

The total nitrogen concentration at this point was the highest among the ones recorded for the sampling points $\left(11,311.2 \mu \mathrm{g} . \mathrm{L}^{-1}\right)$ registered in August 2008, a dry period, during which an accumulation of nitrogen in the water probably occurred. Also during this period the highest ammonium concentration $\left(4,489.6 \mu \mathrm{g} . \mathrm{L}^{-1}\right)$ was registered whereas its lowest concentration was recorded in June 2009 (554.0 $\left.\mu \mathrm{g} . \mathrm{L}^{-1}\right)$. The nitrateand nitrite-nitrogen concentrations were higher in

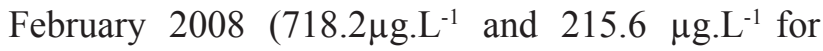
nitrate and nitrite, respectively). The average soluble reactive silica concentration was $15.6 \mathrm{mg} . \mathrm{L}^{-1}$.

At point 10, just downstream the reservoir, the physical and chemical variables showed temporal variations similar to those at point $1 \mathrm{C}$ exhibiting however, a slight improvement in water quality as shown by a significant reduction in electric conductivity which was rarely over $400 \mu \mathrm{S} / \mathrm{cm}$, and higher values of dissolved oxygen, except in October 2008. Furthermore, the total phosphorous values varied between $34.7 \mu \mathrm{g} . \mathrm{L}^{-1}$ and $410.1 \mu \mathrm{g} . \mathrm{L}^{-1}$ in August 2007 and October 2008, respectively. The average value of soluble reactive phosphorous was $21.7 \mu \mathrm{g} . \mathrm{L}^{-1}$, with the highest value found in October $2007\left(103.2 \mu \mathrm{g} . \mathrm{L}^{-1}\right)$ 
and the lowest one in December $2007\left(0.49 \mu \mathrm{g} . \mathrm{L}^{-1}\right)$, probably due to dilution caused by the rains.

The total nitrogen values varied from 1,917.8 $\mu$ g. $\mathrm{L}^{-1}$ in December 2008 to 5,313.0 $\mu$ g. $\mathrm{L}^{-1}$ in February of the same year. The ammonium concentration was high, with the highest value registered in October $2008\left(2,531.5 \mu \mathrm{g} . \mathrm{L}^{-1}\right)$ and the lowest in August 2007 $\left(141,2 \mu \mathrm{g} . \mathrm{L}^{-1}\right)$. The highest nitrate concentration was registered in August 2007 and the lowest in October 2008 (1,176.3 $\mu \mathrm{g} . \mathrm{L}^{-1}$ and $10.3 \mu \mathrm{g} . \mathrm{L}^{-1}$, respectively). The nitrite concentration varied widely between the sampled periods with the maximum value registered in June $2008\left(150.9 \mu \mathrm{g} . \mathrm{L}^{-1}\right)$ and the minimum one $\left(2,0 \mu \mathrm{g} . \mathrm{L}^{-1}\right)$ registered in October 2008. The average concentration of soluble reactive silica was $7.0 \mathrm{mg} . \mathrm{L}^{-}$ ${ }^{1}$ with the maximum value registered in October 2007 and the minimum in February 2008 (20.1 mg. $\mathrm{L}^{-1}$ and $2.6 \mathrm{mg} . \mathrm{L}^{-1}$, respectively).

According to Tundisi \& Matsumura-Tundisi (2008) a reservoir works as a water purifying element since it retains, due to the dam, sediments, particulate nutrients, particulate organic matter and other pollutants and impurities. Thus, it was expected that the waters downstream the reservoir showed lower nitrogen and phosphorous concentrations, higher contents of dissolved oxygen and lower electric conductivity, as shown in Figure 2, comparing points $1 \mathrm{C}$ and 10 for some of these parameters (total-P, ortho-phosphate, total- $\mathrm{N}, \mathrm{NH}^{+}$, electric conductivity, turbidity, content of dissolved oxygen and total dissolved solids). It also shows the MannWhitney's test values. It is important to note that the only non significant difference for both points was for the nitrite- and nitrate-nitrogen concentrations.

These results clearly show that a considerable amount of the high nitrogen and phosphorous loads that enter the reservoir through Ibirité stream (point 1C) are retained at the reservoir which releases water with significantly lower concentrations as measured at point 10 , just downstream the reservoir. This retention is c. $40 \%$ of the total amount of total phosphorous, soluble reactive phosphorous, total nitrogen and ammonium-nitrogen. A higher temporal variability occurs with the phosphorous retention. Normally, the main nutrient stocker of a reservoir is the sediment. However, specifically in Ibirité, it should be considered that the biomass present at the water column's plankton and the large amount of floating and emerging macrophytes present at the shallow waters also act as important nutrient retaining elements and can continually return it to the system through decomposition (in the case of biomass) or through vertical circulation of the water column during the circulation periods in the case of the sediment. Furthermore, a certain portion can also return due to bioturbation, as demonstrated by Callisto et al. (2009) whom recorded release rates of $\mathrm{NH}_{4}^{+}$for Ibirité reservoir due to Chironomus sp larvae varying from 51.92 to $123.56 \mu \mathrm{mol} . \mathrm{m}^{2} . \mathrm{h}^{-1}$ depending on sediment type (sand our mud) and density of benthic organisms.

The primary production, that is, the production of new biomass by aquatic plants is quite expressive at this environment. Data obtained by Santos \& Alves (2009) show that the present trophic situation of Ibirité reservoir is ideal for the high productivity of some macrophyte species such as Eicchornia crassipes (water hyacinth). According to these authors this floating macrophyte was capable of increasing its biomass at the reservoir from $417 \mathrm{~g}$ D.W. $\mathrm{m}^{-2}$ in January 2009 to 804g D.W.m ${ }^{-2}$ in August 2009, an increase of practically $100 \%$ in 6 months! On the other hand its necromass, which indicates decomposition and nutrient cycling, increased from 136 to $155 \mathrm{~g} \mathrm{D.W.m}{ }^{-2}$ in June 2009 and maintained this same level in August 2009.

Besides the large productivity and thus large nutrient retention, the macrophyte and the microscopic algae also contribute to the maintenance of phosphorous and nitrogen circulation in the reservoir. Figure 3 shows the high levels of phytoplankton biomass (chlorophyll-a) registered in sampling points 2, 3, and 4 within the reservoir between October 2007 and October 2008. It is important to note that there is a direct correlation between the concentrations of soluble reactive phosphorous and phytoplankton biomass, although this correlation might be temporal and may alter depending on other variables of the system, such as extinction of the intense light at the water column due to the excess of suspended matter including the algae themselves. 

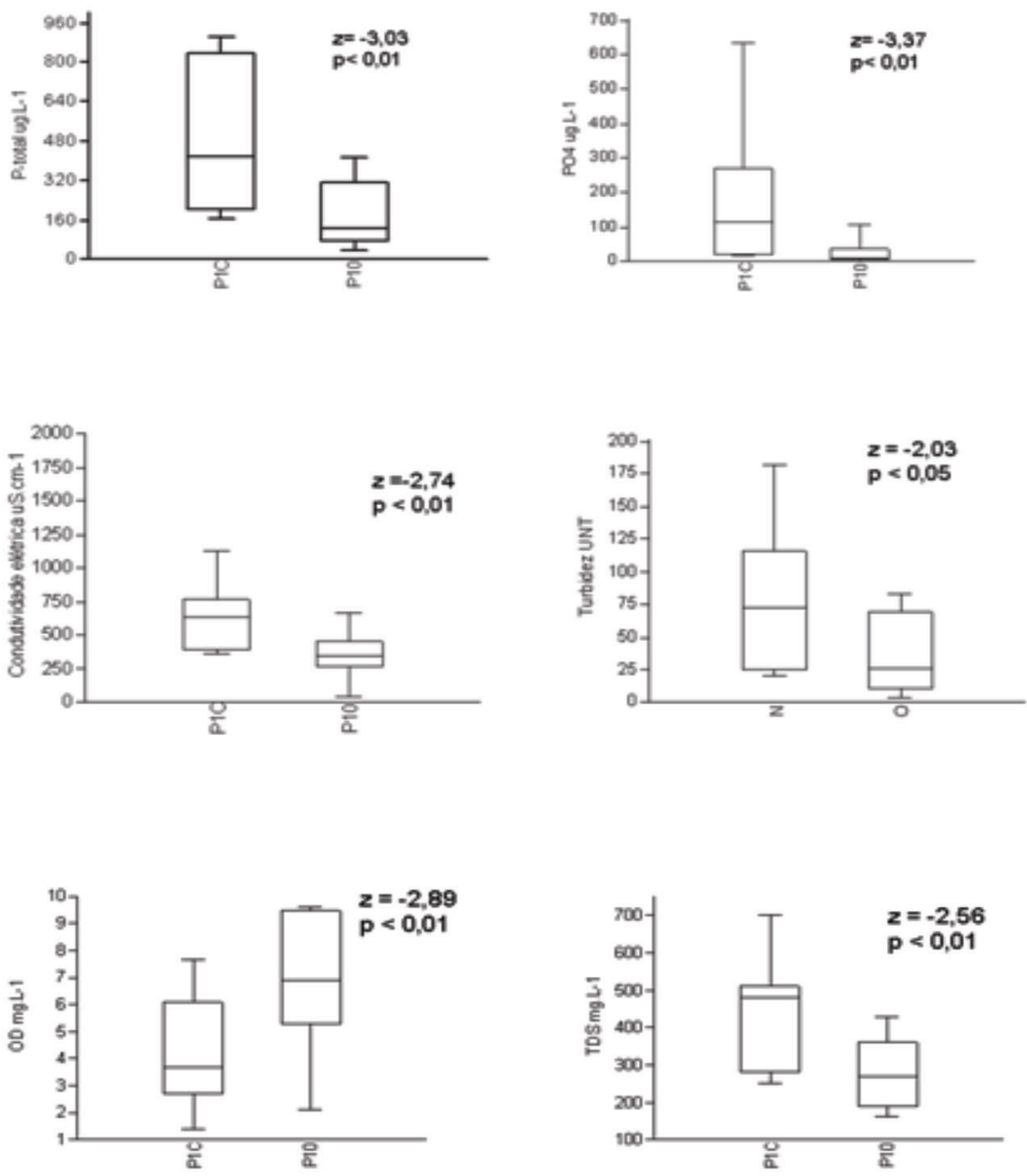

Figure 2. Water quality parameters and values of the Mann-Whitney test at points $1 \mathrm{C}$, upstream, and 10, downstream Ibirité reservoir. Figura 2. Parâmetros da qualidade da água e valores do teste de Mann-Whitney nos pontos 1C, a montante, e 10, a jusante do reservatório de Ibirité.

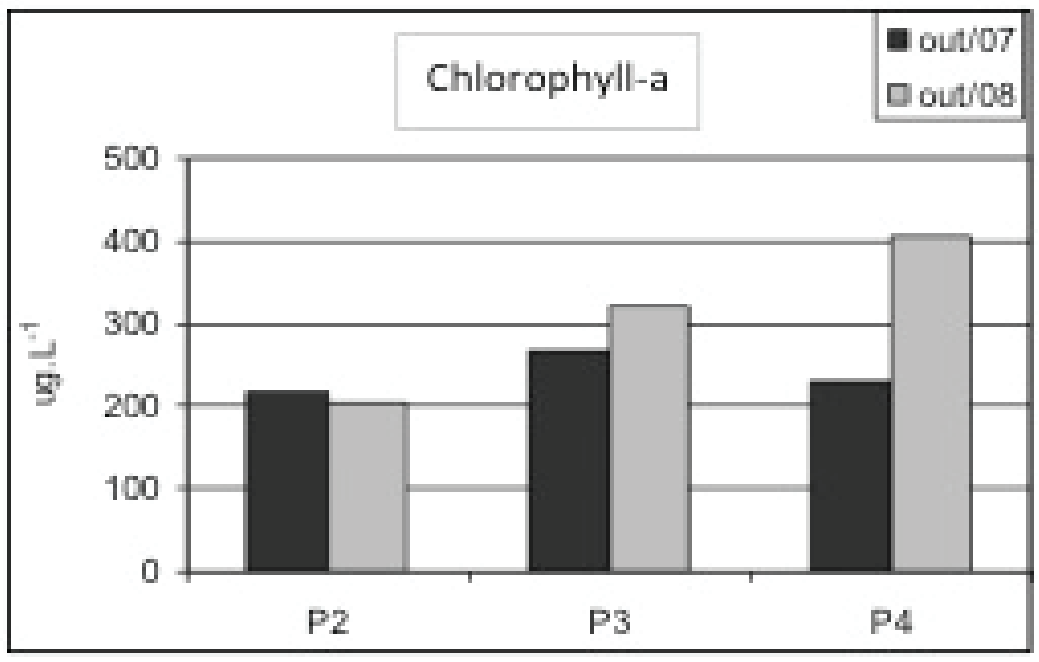

Figure 3. Chlorophyll-a concentration along the period October 2007 and October 2008 at the three sampling points within Ibirite reservoir. Figura 3. Concentração de clorofila-a no periodo de outubro de 2007 a outubro de 2008 nos três pontos de amostragem dentro do reservatório de Ibirité. 
During the entire sampling period, a total of 169 phytoplankton algae species were registered, distributed in 11 taxonomic classes of which Zygnemaphyceae (49 species), Chlorophyceae (45 species) and Cyanophyceae (35 species) were the ones that contributed most to the phytoplankton richness.
The other classes showed the following species contribution: Bacillariophyceae(19), Euglenophyceae (11), Chlamidophyceae (3) Dinophyceae (2), Crypthophyceae (1), Oedogoniophyceae (1), Raphidophyceae (1) and Crysophyceae (1), as shown in Figure 4.

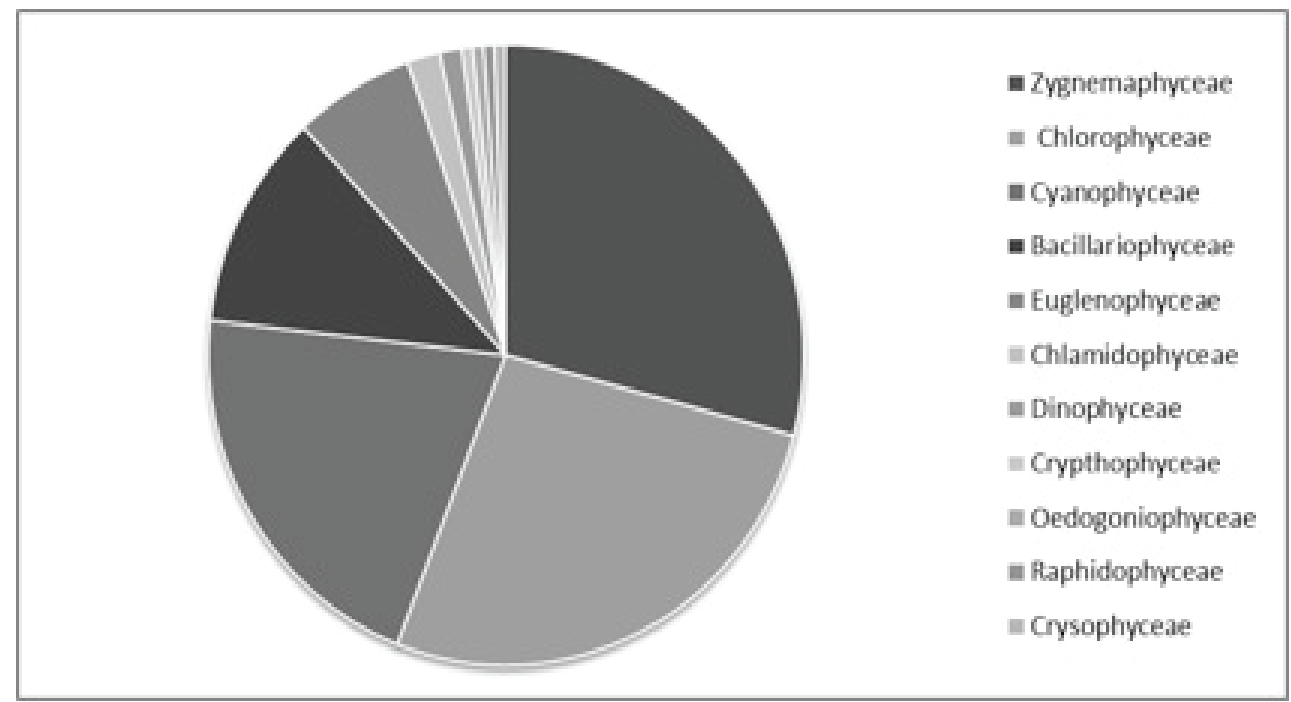

Figure 4. Contribution of the taxonomic classes to the total richness observed at the sampling points at Ibirité reservoir, municipality of Ibirité, MG, during October 2007 and June 2009.

Figura 4. Contribuição das classes taxonômicas em relação á riqueza total observadas nos pontos de amostragem no reservatório de ibirité, município de Ibirité, MG, em outubro de 2007 e Junho de 2009.

Figure 5 presents the total phytoplankton richness in each sampled point during the entire studied period. The highest richness was observed at point 10, with 257 species, followed by points 2,3 and 4 with respectively 227, 221 and 219 species. Point 10, located downstream the reservoir can receive a contribution of more species originated from the reservoir besides those characteristic of lotic systems. The lowest richness value was registered at
Taboões reservoir, taken for this study as a reference point, from where 175 species were recorded. This environment is shaded and oligotrophic, features that very likely limit the development of phytoplankton. At point $1 \mathrm{C}$, upstream the reservoir, in spite of the non-treated and mainly domestic sewage, a total of 179 species was registered, a value considered high in the phytoplankton community, although still lower than the one recorded at point 10 .

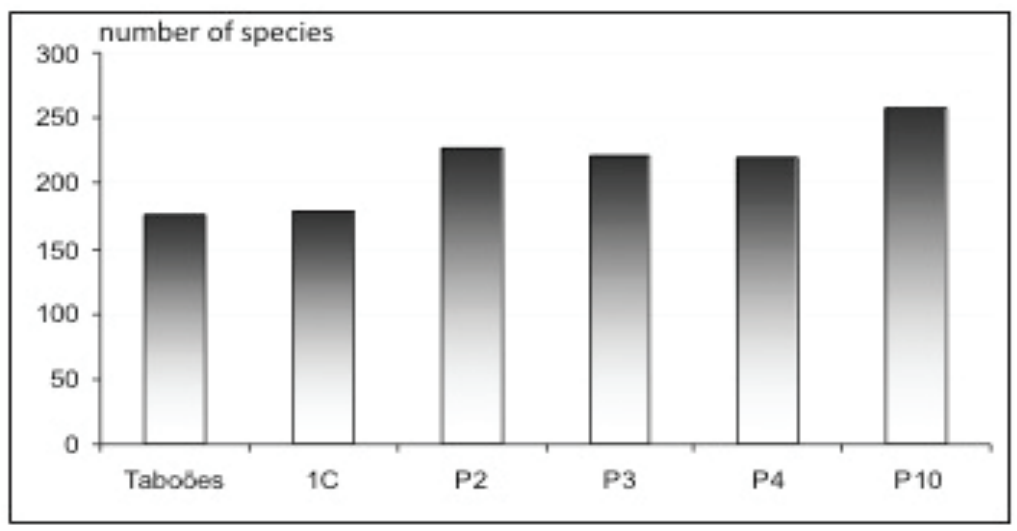

Figure 5. Total richness (absolute number of species) at each sampled point in October and December 2007, February, April, June, August, October and December 2008 and February, April and June 2009.

Figura 5. Riqueza total (número total de espécies) em cada ponto de amostragem em outubro e dezembro de 2007, fevereiro, abril, junho, agosto e dezembro de 2008 e fevereiro, abril e junho de 2009. 
In terms of floristic groups the phytoplankton composition varied from a community numerically dominated by Cyanophyceae at point $1 \mathrm{C}$ to more equal communities between the divisions, as shown in Figure 6 for point 10. These results show the tendency of the biological community to once again present higher richness/diversity after the decrease of the eutrophication levels observed at the reservoir, evidencing the role of suspended matter retention, including nutrient elements thus demonstrating the reservoir's role in improving water quality through this regulating service.

Point $1 \mathrm{C}$ in 7 out of the 11 sampled months showed a higher relative abundance of Cyanophyceae (>80\% of the average density); during February 2009, this class showed almost $100 \%$ of relative abundance at this point, contributing with $5,344.0 \mathrm{org} / \mathrm{mL}^{-1}$. Bacillariophyceae was most abundant in June 2009, June 2008 and April 2009, whereas Cryptophyceae was the most abundant class in October 2008, contributing with $90 \%$ of the total abundance $(1,919.8$ org $/ \mathrm{mL}^{-1}$ ) (Figure 6).

The Cyanophyceae class was the most abundant in April 2008 and April 2009, contributing with over 80\% of the relative abundance and also in December 2007, contributing with over $50 \%$ of the relative abundance (Figure 6). The Chlorophyceae's participation can be noted in more than half the samples at this point.

The phytoplankton's richness was considerably higher at the point upstream the reservoir and the algae density (Figure 7) was altered by the reservoir's presence. When comparing the phytoplankton community's density at points $1 \mathrm{C}$ and 10 it can be noted that within the reservoir this community finds ideal conditions for the growth of its various populations such as high light intensity, high nutrient concentrations, high temperatures and higher water retention time. In 7 out of 11 samplings the algae density at point 10 is at least $10^{4}$ times higher than at point $1 \mathrm{C}$ showing how the higher phytoplankton density within the reservoir is retained upstream the dam. At point $1 \mathrm{C}$, despite the higher nutrient concentration and temperature light is probably limited due to the high turbidity caused by the large amount of suspended solids. The dark color of the stream at this point suggests the biologic community must be formed mainly by heterotrophic and decomposers organisms such as bacteria which isn't favorable to the development of primary plankton producers.

All this large biomass will, at a certain time, decompose and release the stocked nutrients to the water column. Gonçalves \& Resende (2009) comparing the decomposition of two aquatic plant species Typha domingensis and Eicchornia crassipes (water hyacinth) in Taboões and Ibirité showed that the decomposition coefficients found in Ibirite could be considered fast, mainly in respect to the water hyacinth. This species has lower levels of lignin and cellulose in its tissues compared to those of $T$. domingesis, compounds which are difficult to be decomposed thus explaining the differences in decomposition rates (Bianchini 2003). The high levels of nitrogen and phosphorous in the water are capable of accelerating the microbial metabolism of fungus and bacteria which in turn, can accelerate the degradation of the colonized plant tissues intensifying the velocity of decomposition at Ibirité reservoir.

Besides the rapid internal nutrient circulation due to the primary production and decomposition processes of the plant biomass artificial tropical reservoirs also have in their bottom sediment and in the interstitial water that flows through it, a gigantic stock of nitrogen and phosphorous (internal loading). Such stock may, under certain circumstances, be kept inert and isolated from the sediment or, in certain periods of the year, when the environmental and climate conditions alter, be brought back to the water column and contribute to the processes of eutrophication and aging of the water body. Depending on the conditions of the hipolimnium oxygenation, mainly at the water-sediment interface, phosphorous can be precipitated onto the sediments as ferric phosphate or, in conditions of anaerobiosis, be re-dissolved in the water column, as soluble reactive phosphorous, ready to be assimilated by the primary producers, as demonstrated by Mozeto et al. (2008) and showed in Table 1. 
Table 1. Percentage of total carbon (CT), total organic carbon (COT), total nitrogen (NT) and total phosphorous (PT) concentrations in the sediments of distinct compartments of Ibirité watershed, including Taboões reservoir.

Tabela 1. Porcentagem de carbono total (CT), carbono orgânico total (COT), nitrogênio total (NT) e fósforo total (PT) nos sedimentos de compartimentos distintos da bacia hidrográfica de Ibirité, incluindo o reservatório de Taboões.

\begin{tabular}{ccccc}
\hline Sample & CT (\%) & COT (\%) & NT(\%) & PT $\left(\mathbf{m g ~ k}^{-1}\right)$ \\
\hline P02 & 2.85 & 2.51 & 0.49 & 1445.59 \\
P03 & 3.35 & 3.00 & 0.53 & 1443.87 \\
P04 & 2.21 & 1.84 & 0.43 & 1413.98 \\
P1C & 1.27 & 0.76 & 0.33 & 915.42 \\
P10 & 0.47 & 0.07 & 0.32 & 189.98 \\
Taboões & 6.51 & 3.24 & 0.54 & 734.27 \\
\hline
\end{tabular}

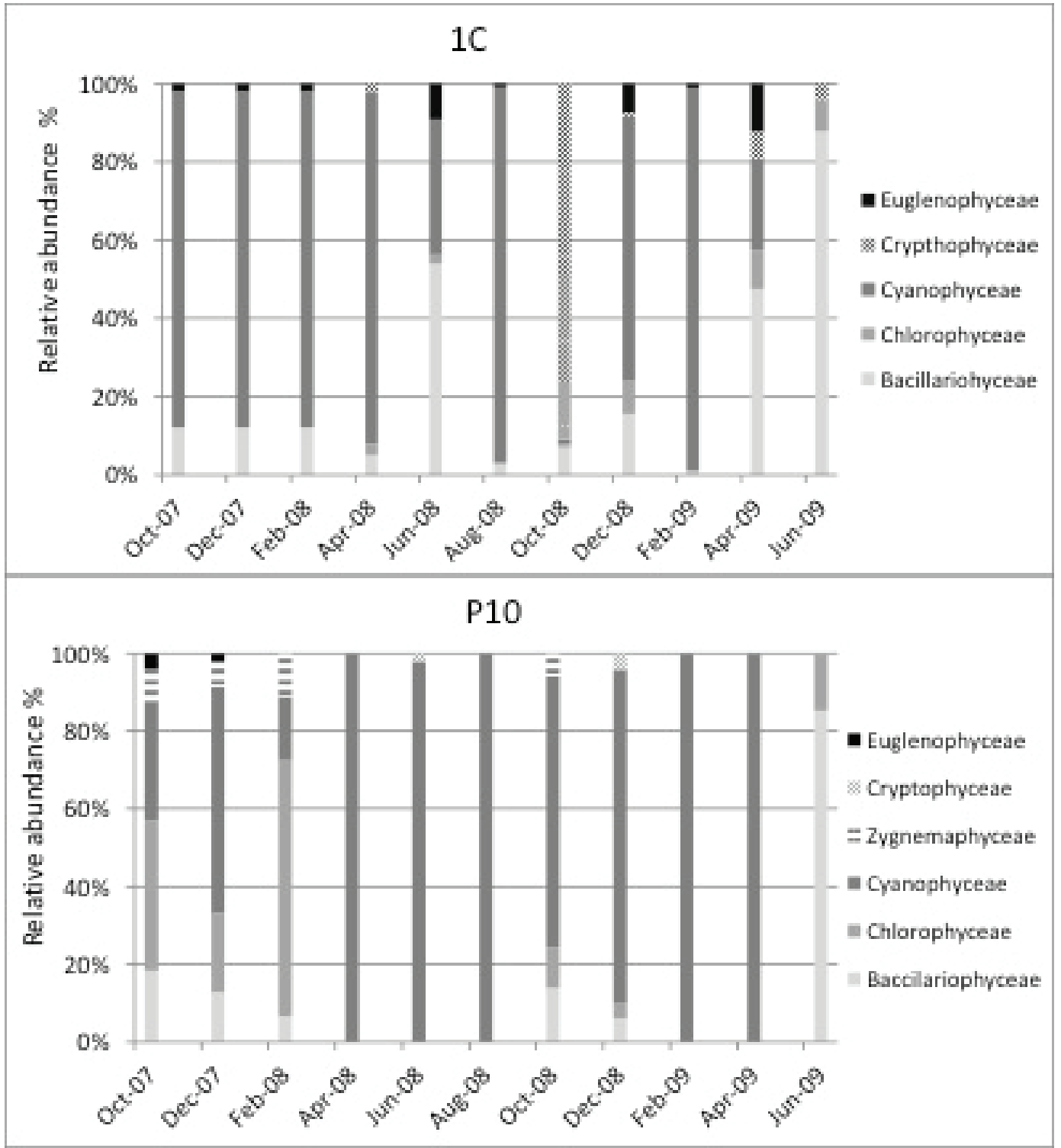

Figura 6. Relative abundance and contributions of the phytoplankton classes (\%) at points 1C (entrance of Ibirité stream) and 10 (downstream Ibirité reservoir) along the studied period.

Figura 6. Abundância relativa e contribuição das classes de fitoplâncton (\%) nos pontos 1C (entrada do rio Ibirité) e 10 (a jusante do reservatório de Ibirité) durante o periodo de estudo. 


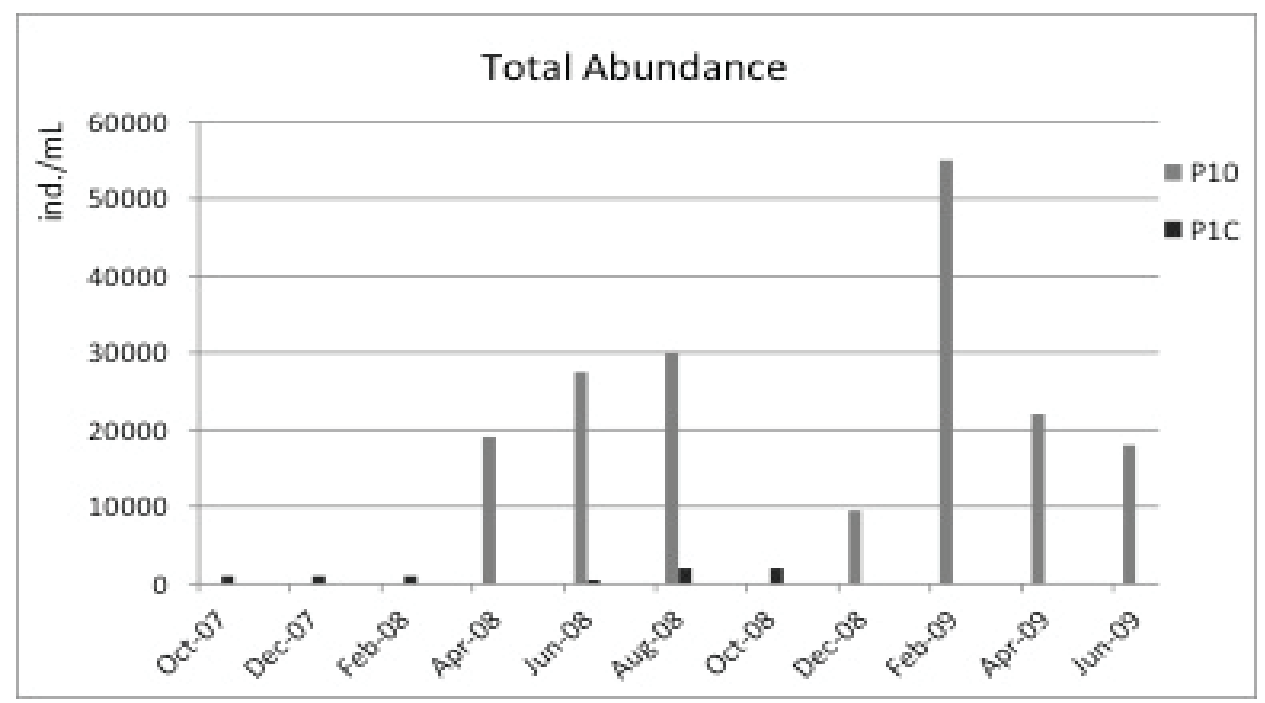

Figure 7. Total phytoplankton abundance (ind.mL-1) at points $1 \mathrm{C}$ and 10, Ibirité reservoir, municipality of Ibirité, MG. Figura 7. Abundância total de fitoplâncton (ind. $m L-1$ ) nos pontos $1 C$ e 10, no reservatório de Ibirité, $M G$.

\section{DISCUSSION}

The monitoring of the physical and chemical variables of the water and the phytoplankton community of Ibirité reservoir along two hydrologic cycles showed an intense environmental degradation and loss in water quality. However, an improvement of the water quality that leaves the reservoir is also clear as indicated by the lower nutrient concentration, higher oxygenation and substitution of floristic groups that indicate waters with organic contamination by other types of less enriched and/or eutrophic environments.

Similar results were found by Barbosa et al. (1999) in studies in the reservoir cascade of middle/lower River Tietê assessing the effects of the sequence of 7 reservoirs (cascade) on the physical, chemical and biological qualities of the water. In each reservoir changes were observed in the water characteristics caused by the discontinuity of the physical and chemical gradients of the lotic system, leading to a pattern of alterations entitled Cascade Reservoir Continuum-CRC. All the alterations in the physical and chemical patterns observed at this continuum converged to improve the water quality downstream the River Tietê. Thus, a reduction of turbidity in the first reservoir was registered, followed by less intense decreases in this parameter in the six subsequent reservoirs.

The phytoplankton biomass and chlorophyll-a concentration increased in the first three reservoirs due to their high organic charge carried by River Tietê after receiving, amongst others, sewage from São Paulo, but decreased drastically soon after the third reservoir. In this forth reservoir, a change towards a more diverse phytoplankton community characteristic of oligotrophic environments occurred. The improvement in oxygenation of the waters throughout the cascade was also clear, mainly after the third reservoir.

The algae community hence showed downstream the reservoir a numeric dominance of Chlorococcales and Desmidiales whereas the cyanobacteria had their numeric importance reduced to insignificant levels, a situation quite different from the upstream reservoirs, dominated by diatomacea and cyanobacteria (Barbosa et al. 1999).

According to von Sperling (1996) the cost of implantation of a sewage treatment system, capable of reducing in $c .40 \%$ the $\mathrm{N}$ and $\mathrm{P}$ water concentrations, partially and naturally done for free by the Ibirité reservoir can vary between UD\$10 and UD $\$ 1200.00$ per inhabitant depending on the type of system used. The cheapest ones are those of facultative lagoon, anaerobic lagoon + facultative lagoon, aired lagoon, aired lagoon + decantation lagoon and the most expensive ones are the conventional iodine activated and bio discs. Assuming the number of inhabitants of the municipality of Ibirité of 159,026 (IBGE, 2010) and the fact that none of them have sewage treatment it can be inferred that Ibirite reservoir realizes a service that, for its implantation alone (without the 
maintenance costs) wouldn't cost less than US\$ 1,590.000.00 an amount saved by the population or the public savings thanks to the regulation of the environmental services (water quality improvement) and provision (water supply).

Even if these services' cost may contain estimative and scale errors it is undeniable that Ibirité reservoir contributes significantly to the water quality improvement as shown by the comparison of values measured at the reservoir's entrance (point 1C) and just downstream (point 10). This information should be included in the reservoir's recovery and management plans, particularly in the proposal of implantation of sewage treatment systems in the municipality, either by the construction and operation of an artificial wetland or by a conventional sewage treatment station (STS) since the dimensioning of such systems is directly affected by the reservoir's efficiency in "retaining sewage and polluters" and liberating better quality water downstream the reservoir. Such efficiency depends, surely, on the amount of sewage that arrives at the reservoir which can be substantially reduced by building an artificial wetland just downstream point $1 \mathrm{C}$ as suggested by the technical-scientific report of Ibirité Project - Phase II (2009).

\section{REFERENCES}

ANDRADE, D.C. \& ROMEIRO, A.R. 2009. Serviços ecossistêmicos e sua importância para o sistema econômico e o bem-estar humano. Texto para Discussão. IE/UNICAMP, Campinas.

BARBOSA, F.A.R.; PADISÁK, J.; ESPÍNDOLA, E.L.G.; BORICS, G. \& ROCHA, O. 1999. The cascading reservoir continuum concept (CRCC) and its application to the river Tietebasin, São Paulo State, Brazil. Pp. 425-437. In: J.G. Tundisi \& M. Straskraba (eds.). Theoretical Reservoir Ecology and its Applications. International Institute of Ecology, São Carlos.

BICUDO, C.E.M. \& MENEZES, M. 2005. Gêneros de algas continentais do Brasil - Chave para a identificação e descrições. São Carlos. 508p.

BOURRELLY, P. 1968. Les algues d'eau douce - Inititaion à la systématique. Tome II: Les algues jaunes et brunes. Éditions M. Boubée \& Cie. Paris. 437p.
BOURRELLY, P. 1972. Les algues d'eau douce - Inititaion à la systématique. Tome I: Les algues vertes. Éditions M. Boubée \& Cie. Paris. 572p.

BOURRELLY, P. 1985. Les algues d'eau douce - Inititaion à la systématique. Tome III: Les algues bleus et rouges. Éditions M. Boubée \& Cie. Paris. 509p.

CALLiSTO, M; FONSECA, J. J. L.; FIGUEIREDO, M. P.; PAULA, P. M. S.; ESTEVES, F. A. 2009. Effect of bioturbation by Chironomus on nutrient fluxes in an urban eutrophic reservoir. pp. 76-86. In: The International Conference of Science and Information Technologies for Sustainable Management of Aquatic Ecosystems, Concepción. Organizing Committee Eds. 7th International Symposium on Ecohydraulics. Concepción: Universidad de Concepción,v. 1.

FIALA, L. \& VASATA, P. 1982. Phosphorus Reduction in a ManMade Lake by Means of a Small Reservoir on the Inflow. Archiv fur Hydrobiologie, 94 (1): 24-37.

HAMMER, Ø.; HARPER, D.A.T. \& RYAN, P. D. 2001. PAST: Paleontological Statistics Software Package for Education and Data Analysis. Palaeontologia Electronica, 4(1): 9.

LUND, J.W.G.; KIPLING, G. \& LE CREN, E.D. 1958. The inverted microscope method of estimating algal numbers and the statistical basis of estimations by counting. Hydrobiologia, 11 (2): $143-170$

MILLENNIUM ECOSYSTEM ASSESSMENT, 2005a. Ecosystems and Human Well-being: Synthesis. Island Press, Washington, DC. 137p.

MILLENNIUM ECOSYSTEM ASSESSMENT, 2005b. Ecosystems and Human Well-Being: wetlands and water Synthesis. World Resources Institute, Washington, DC. 68p.

MOZETO, A.A. 2008. Projeto Ibirité Fase II - Relatório No2 - Confirmação de Diagnóstico Ambiental da Represa Ibirité. Laboratório de Biogeoquímica Ambiental. DQ-UFSCar. São Carlos - SP. 93p.

PRESCOTT, G.W. 1975. Algae of the western great lakes area. Sixth Edition. W.M.C. Brown Company Publishers, USA. 977p.

PRESCOTT, G.W.; CROASDALE, H.T. \& VINYARD, W.C. 1975. A synopsis of North American desmids. Part II. Desmidiaceae: Placodermae. University of Nebraska press. $275 \mathrm{p}$.

PRESCOTT, G.W.; CROASDALE, H.T. \& VINYARD, W.C. 1975. A synopsis of North American desmids. Part II. 
Desmidiaceae: Placodermae. Section 2. University of Nebraska press. $413 p$.

REDDY, K.R. 1983. Fate of Nitrogen and Phosphorus in a Wastewater Retention Reservoir Containing Aquatic Macrophytes. Journal of Environmental Quality, 12(1): 137-141.

RELATÓRIO DE ANDAMENTO DE PROJETO V. 2009. $A$ qualidade ambiental das sub-bacias dos Ribeirões Ibirité $e$ Pintados: uma proposta de gestão integrada do Reservatório de Ibirité, Município de Ibirité-MG. Belo Horizonte, 225 p.

SANT'ANNA, J.C. 1984. Chloroccocales (Chlorophyceae) do Estado de São Paulo, Brasil. J. Crames: Alemanha. 348pp.

SANTOS, A. \& ALVES, A. 2009. Monitoramento da comunidade de macrófitas aquáticas no reservatório de Ibirité, MG. Relatório técnico. $225 \mathrm{p}$.

STRA ŠKRABA, M.; DOSTÁLKOVÁ,I.;HEJZLAR, J. \&VYHNÁLEK, V. 1995. The Effect of Reservoirs on Phosphorus Concentration. Internationale Revue der gesamten Hydrobiologie und Hydrographie, 80: 403-413.

TUNDISI, J.G. \& MATSUMURA-TUNDISI,T. 2008. Limnologia. Oficina de Textos, São Paulo. 631 p.

UTERMÖHL, H. 1958. Zur Vervollkommnung der quantitativen Phytoplankton-Methodik. Mitteilungen Internationale Vereinigung für Theoretische und Angewandte Limnologie, 9: 1-38.

VILLAFAÑE, V.E. \& REID, F.M.H. 1995. Metodos de microscopia para la cuatificacion del fitoplancton. Pp. 169185. In: K. Aveal \& M.E. Ferrario (eds.). Manual de métodos ficológicos. Oliveira, E.C. \& Sar, E. Universidad de Concepción, Chile.

VON SPERLING, M. 1996. Princípios do tratamento biológico de águas residuais. Introdução à qualidade das águas e ao tratamento de esgotos. $3^{\text {a }}$ Edição. Departamento de Engenharia Sanitária e Ambiental, Universidade Federal de Minas Gerais. Belo Horizonte. 211 p.

Submetido 08/08/2011

Aceito 10/08/2011 